\title{
Spatial and Environmental Condition of Bajo Tribe Settlement in South Halmahera
}

\author{
Mustamin Rahim ${ }^{1}$, Ardi Basri ${ }^{2}$, Hendra Fauzi ${ }^{3}$ \\ Department of Architecture \\ Universitas Khairun \\ Ternate, Indonesia \\ 1'mustamin_rahim@yahoo.co.id
}

\begin{abstract}
This study aims to identify the spatial characteristics of Bajo Tribe settlement around coastal areas in South Halmahera, environmental analysis and settlement conditions by literature review and field observation. The results show that the existence of Bajo Tribe in North Maluku deployment in coastal areas, especially in Sula and Kayoa districts. Bajo ethnic settlements are generally located in areas of mangrove forest with the settlement condition is slum and are not equipped with adequate facilities and infrastructure for supporting community activities. Deployment of Bajo Tribe settlements is not accompanied by sustainable environmental arrangement. Bajo Tribe generally working as traditional fisherman with limited fish catching; therefore their earning cannot improve their welfare.
\end{abstract}

Key words: bajo tribe; settlement; fisherman

\section{INTRODUCTION}

Indonesia is known as the maritime nation and the largest archipelago nation in the world. Which is lies between the Indian and Pacific oceans as well as the continents of Asia and Australia, which have high cultural, ethnic and linguistic, and abundant of natural resources. The width of Indonesian ocean is estimated to reach 5.8 million $\mathrm{km} 2$, that consists of 0.8 million $\mathrm{km} 2$ of territorial sea, 2.3 million $\mathrm{km} 2$ of marine archipelago, and 2.7 million $\mathrm{km} 2$ Exclusive Economic Zone of Indonesia. The world's longest coastline is $81,000 \mathrm{~km}$ and as many as 17,504 islands. Therefore, the ancestor of the Indonesian nation is known throughout the world as sailor.

North Maluku is a region that has potential of abundant coastal resources. Several coastal areas of North Maluku are habited by fisherman from Bajo tribe. Bajo Tribe Settlements are slums with low income and limited of facilities and environmental infrastructures [1-4]. Bajo tribe usually build their settlement on the sea, but still in the water side, not on the landslide [5]. Based on the initial identification of Bajo Tribe in North Maluku is spread in several coastal areas, including: Sula Islands, South Halmahera, East Halmahera, and West Halmahera. Therefore, this paper will discuss the deployment and development of Bajo tribe settlements in North Maluku.

\section{RESEARCH METHODOLOGY}

This research is qualitative research that emphasizes on the identification of the form and characteristics of settlements, as well as the behavior of the Bajo tribe, through: (1) Field study: direct observation in the field to obtain primary data, directly from the field about the deployment and development of Bajo tribe settlements. (2) Literature review: to get complement secondary data information about the development of coastal areas of Kayoa especially Laluin and Posi-Posi villages, their economic and social conditions, institutional and development programs. (3) Interviews: to obtain information, relating primary and secondary data to supplement data that obtained through field studies and literature studies

\section{RESULTS AND DISCUSSIONS}

A. Characteristics of Bajo Tribe Settlements

The Bajo tribe is a traditional and skilled fisherman and his life is entirely dependent on the sea, they are often referred to as sea nomad or "sea people"[6]. The term "Bajo", "Bajo Tribe", or "Bajo Man", is commonly used by residents of eastern Indonesia to refer to these sea nomadic nomads, scattered in various regions [7].

The lifestyle of Bajo tribe is very unique and different from other tribes. Their lifestyles must always be connected to the water or sea because their livelihoods are fishermen, Therefore, they always live in coastal areas and have potential marine resources. At first, the Bajo tribe lived in the boat (lepa), in the boat there are food and fishing equipment like a house on the mainland. This is done because of their habit of living on water. Behavior of life on the water has become the characteristics and customs of the Bajo Tribe, so that, it is very difficult to relocate to the mainland area. In addition, the Bajo people's do not have expertise to grow crop so that, they difficult to live on land [8-10].

Along with the development of the mindset of the Bajo tribe, they began to make simple homes as temporary dwellings by using wood materials for columns and beams, and palm leaves as wall and roof. This house function is as a residence and storage of their catch and catching equipment. The temporary dwellings are constantly develope and 
eventually become permanent settlements. The settlement is built on water, as a character of the Bajo People's life.

\section{B. Deployment of Bajo Tribe Settlements}

Bajo Tribal Settlements in North Maluku spreads across several coastal areas, including: Sula Islands, East Halmahera, West Halmahera, and South Halmahera. Therefore, in this paper will discuss the deployment and development of Bajo tribal settlements, especially in the area of Southern Halmahera, which is the largest Bajo tribe population in North Maluku.

Bajo Tribe in North Maluku is began to settle in the 1900 s, originally was immigrant from Sulawesi Island. They sailed to the eastern region and tracing the southern islands of North Maluku: Sula Islands, Taliabu, and South Halmahera. The arrival of the Bajo tribe in Laluin was caused by the potential of surrounding marine resources, such as: fish, sea cucumbers, and pearls. Bajo tribe have an important role in the history of Moloku Kieraha Sultanate (the sultanate of Jailolo, Ternate, Tidore and Bacan), where one of its warlords comes from the Bajo tribe, who was Kapita Ali. He was chosen as a warlord because he was an expert in strategies of island warfare.

Bajo settlements in Laluin village grow and flourish is influenced by the potential of marine resources in surrounding area. It is located in Waidoba Island, which is safe from high waves and including shallow area. Thus, the Island is very safe to tether the boat and also as a potential fishing area. Their fish catching can support the minimum needs of the community, therefore the Bajo Tribe build simple houses from material of wood as columns and beams, palm leaves for walls and roofs. Settlements of Bajo Tribe in Laluin village grow and develop until now with the tradition and a culture are still awake. Along with the increasing number of residents of Bajo tribe, a new settlement is formed in the territory of Waidoba Island. Furthermore, the development of settlements in this region continues to increase and become a definitive village.

Populations of Laluin Village in 2016 are 2609 peoples, with total of 495 families, while the populations of Posi-Posi Village in 2016 are 1071 peoples and 245 families. Economic activities of both communities are dominanted by fishermen and some farmers, traders and government employees. Based on the results of interview with Ibrahim Yunus, got information that the people of Bajo in Laluin and Posi-Posi Villages is embraced Islam and maintained the traditions and culture of the Bajo Tribe although married to other tribes.

\section{Development of Bajo Tribe Settlements}

The increasing of population strongly gives influence of the land usage, so if there is no good design, it will cause negative impact on the preservation of settlement environment and also can cause social and economic impacts due to lack of employment and economic limitations.

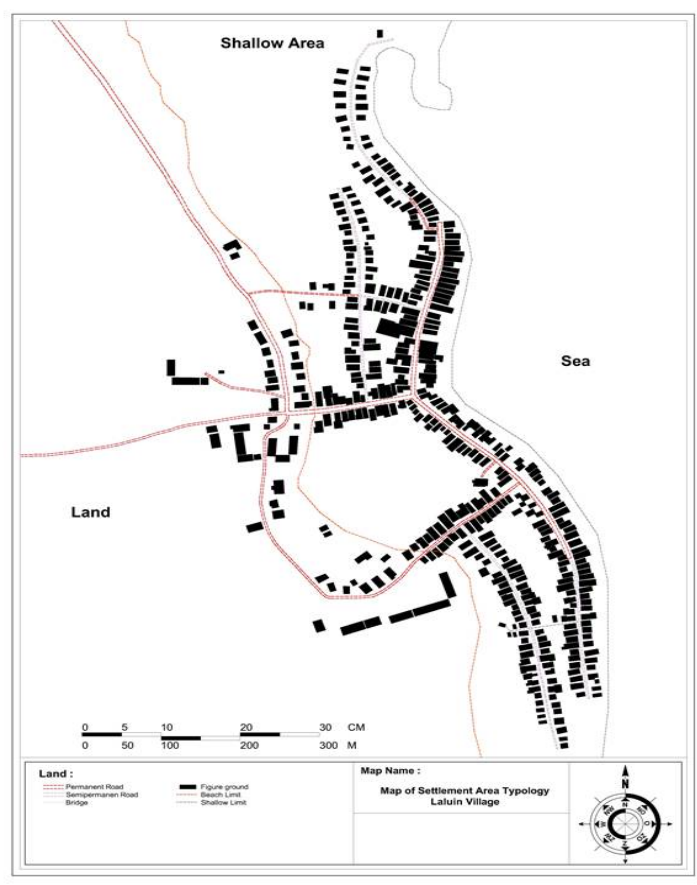

a. Laluin Village

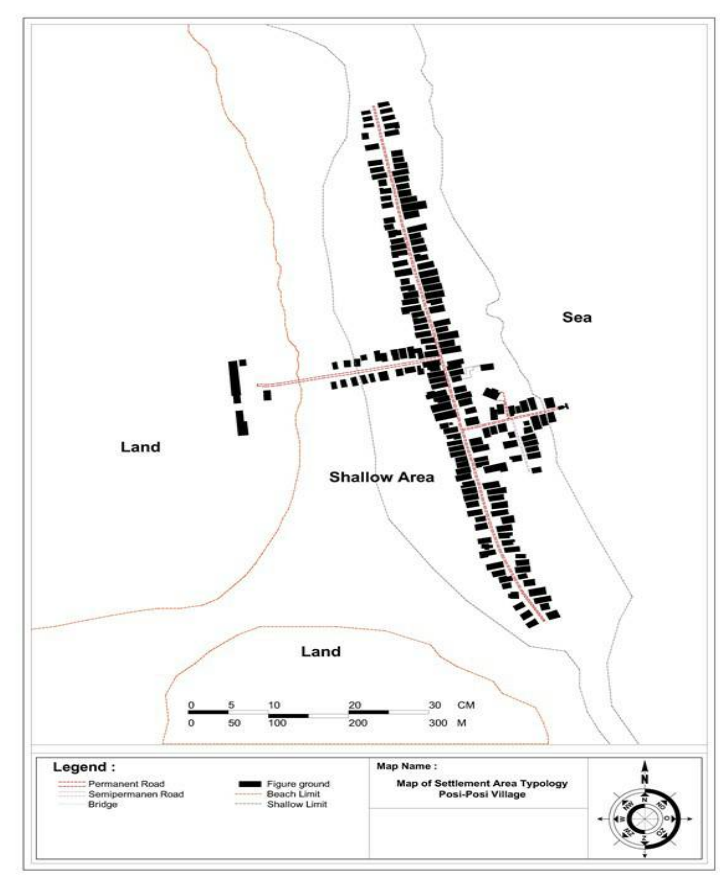

b. Posi-posi Village

Fig. 1. Deployment of Bajo Tribe Settlement

Source: Analyzed, 2017 


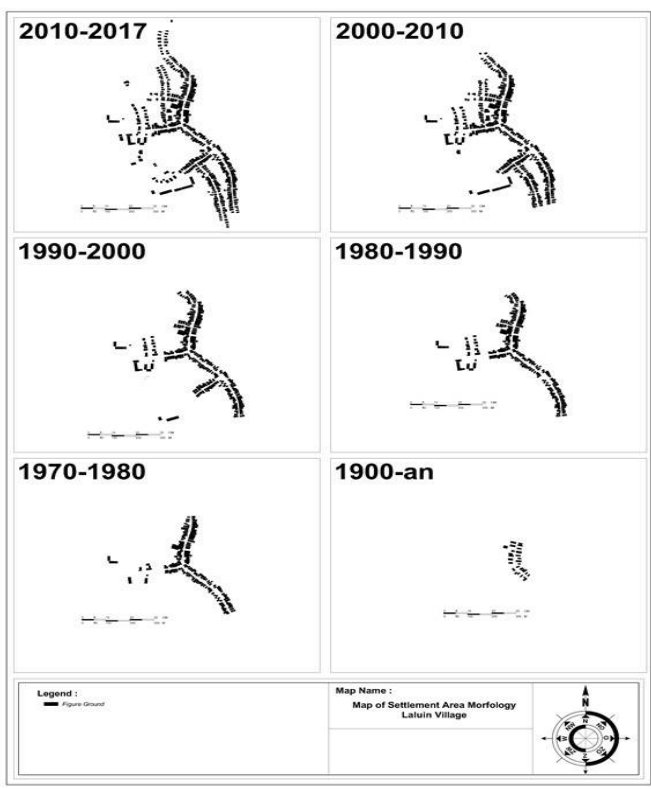

a. Laluin Village

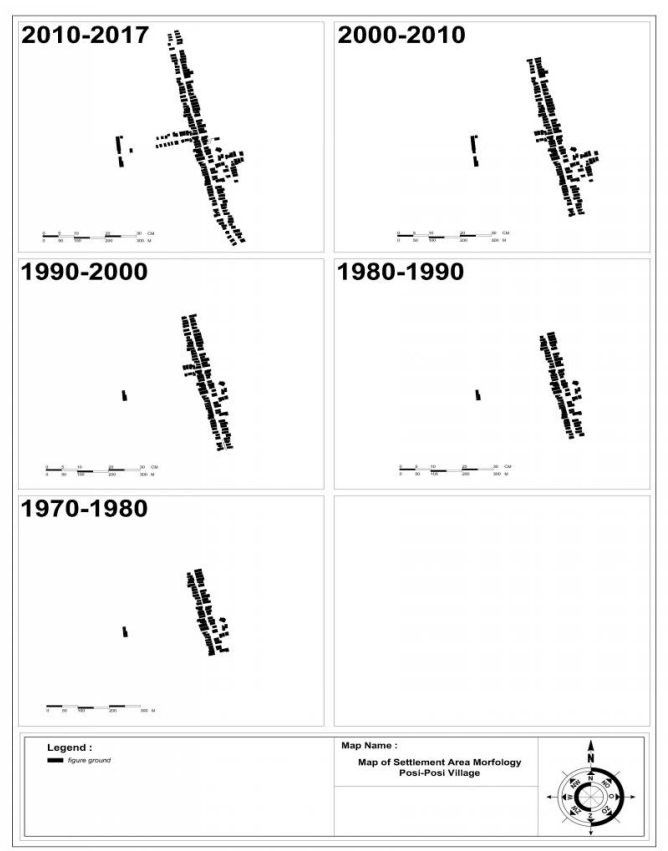

b. Posi-posi Village

Fig. 2. Development of Bajo Tribe Settlements.

(Source: Analyzed 2017)

Results of survey showed that the settlement of Bajo tribe in Laluin is located in an area that surrounded by shallow areas and it has good fishery potential, which is also close to the mainland. But the source of fresh water is not available, so that, it must be supplied from other district.

Since 1970, Bajo tribal settlements in Laluin have grown rapidly to date due to significant fishery potential. In addition, the high population growth so expanded into the capital district. This condition is almost the same in the Posiposi village which is initially only a small village that inhabited by several families, and the number of population, continues to increase and become the definitive village within the administrative area of South Kayoa District.

Settlements in both villages grew spontaneously. With home deployment continues to increase every year naturally and without planning. Thus, the settlement is not well ordered, as well as environmental facilities and infrastructure that do not meet the standards. This condition makes the settlements seem dirty and it needs sustainable arrangement (see Fig. 2).

\section{CONCLUSIONS}

Bajo Tribe in North Maluku begun to settle in the 1900s, originally was immigrant from Sulawesi Island. Bajo Tribal Settlements spreads across several coastal areas, including: Sula Islands, East Halmahera, West Halmahera, and the largest in South Halmahera especially in Laluin and Posi-Posi Villages. Settlements in both villages grew spontaneously. With home deployment continues to increase every year naturally and without planning.

Previously, Bajo tribe build simple homes on the water as temporary dwellings and storage of catch and equipment by using wood materials for columns and beams, and palm leaves for walls and roofs, and then the temporary dwellings are constantly develop and eventually become permanent settlements. The pattern of deployment of Bajo Tribe settlements is linear in Posi-Posi Village and circular in Laluin village with following shallow land condition.

\section{REFERENCES}

[1] Soemarjan, Rumah dalam Dimensi Waktu, Surabaya: ITS, 1991.

[2] Undang No 4 Tahun 1992 tentang Perumahan dan Permukiman, 1992, download from https://www.bphn.go.id.

[3] Keputusan Menteri Permukiman dan Prasarana Wilayah Republik Indonesia nomor 403/KPTS/M/2002 tentang Pedoman Teknis Pembangunan Rumah Sederhana Sehat, 2002, download from https://pembiayaan.pu.go.id.

[4] Keputusan Menteri Kesehatan RI Nomor 829/Menkes/SK/VII/1989. tentang Persyaratan Kesehatan Perumahan (Prinsip Rumah Sehat Menurut WHO), 1989, download from https://peraturan.bkpm.go.id.

[5] F.R. Zacot, Orang Bajo Suku Pengembara Laut, Jakarta: GramediaEFEO-FJP, 2008.

[6] Anwar, "Kajian Pendidikan dan Kebudayaan Bajo, Tinjauan Historis dan Kontemporer," unpublished.

[7] S. Satar, "Pola Spasial Permukiman Suku Bajo di Torosiaje Laut, Provinsi Gorontalo," unpublished.

[8] N.J. Habraken, "The Systematic Design of Support Massachusset, Laboratory of Arc and Planning MIT," unpublished.

[9] Rossi, House, Form and Culture, New York: Prentice Hall, 1982. 